TAO, Vol. 15, No. 4, 609-627, November 2004

\title{
Investigating Subsurface Structures and P- and S-wave Velocities in the Taipei Basin
}

\author{
Chien-Ying Wang ${ }^{1, *}$, Yi-Hen Lee ${ }^{1,2}$, Mang-Long Ger ${ }^{3}$, Yi-Ling Chen ${ }^{1}$
}

(Manuscript received 5 February 2004, in final form 30 July 2004)

\begin{abstract}
Over the past 10 years, the Central Geological Survey (CGS) has conducted a wide-range of investigations of the Taipei basin by drilling over 30 wells $(100-700 \mathrm{~m})$. During the same period, we have also scanned the basin area $(20 \times 20 \mathrm{~km})$ using over 300 shallow reflection seismic lines. The purpose of this paper is to compile these seismic data, incorporating it with the borehole drilling results, to better describe the Tertiary basement, and the Quaternary layers above the basement including their respective $\mathbf{P}$ - and $\mathrm{S}$ wave velocities. It is found that 1 ) the deepest part of the basin basement is probably at the outlet of the Tanshui River, i.e., at the NW corner of the basin, 2) the Kanchiao fault forms a separation boundary bisecting the basin into a deep NW part and a shallow SE part, 3) the Sungshan and Chingmei Formations are relatively flat deposits at the top, which implies the existence of a comparatively quiet deposition period since about 100 thousand years ago, 4) the $P$ - and $S$-wave velocities inside the basin are 1500 - 2200 $\mathrm{m} \mathrm{s}^{-1}$ and $170-880 \mathrm{~m} \mathrm{~s}^{-1}$, and $3000 \mathrm{~m} \mathrm{~s}^{-1}$ and $1500 \mathrm{~m} \mathrm{~s}^{-1}$ for the basement.
\end{abstract}

(Key words: Taipei basin, Shallow reflection seismics, Basin structure, $P$ and $S$ velocities)

\section{INTRODUCTION}

Taipei city, the capital of Taiwan, is located in the Taipei basin. The thick recent deposits in this "soft" basin have caused significant earthquake damage due to site amplifications, although the earthquakes have mostly occurred outside the basin (Sokolov et al. 2001). A severe building collapse caused by the 1999 Chi-Chi earthquake ( $\mathrm{Mw}=7.6$; epicenter $200 \mathrm{~km}$

\footnotetext{
${ }^{1}$ Institute of Geophysics, National Central University, Chung-Li, Taiwan, ROC

2 Energy \& Resources Laboratories, Industrial Research Institute of Technology, Hsinchu, Taiwan, ROC

3 Institute of Geography, National Taiwan Normal University, Taipei, Taiwan, ROC

* Corresponding author address. Prof. Chien-Ying Wang, Institute of Geophysics, National Central University, Chung-Li, Taiwan, ROC; E-mail: wangcy@cc.ncu.edu.tw
} 
to the south) is a recent example (Tsai and Huang 2000). The Taipei basin is triangular in shape (Fig. 1) with an area of about $20 \mathrm{~km} \times 20 \mathrm{~km}$. Four young formations are found sitting flat above the basement which is at most $700 \mathrm{~m}$ deep (CGS 1999; Teng et al. 2001). The top near-surface layer, called the Sungshan Formation, is thought to carry the burden of the siteeffects because of its loose sand and silt content.

Besides weak surface conditions, there are also three significant faults that traverse the basin (Fig. 1b). Of these, the Sanchiao fault, along the NW border of the basin, has a good possibility of being active (Bollina 1977; Lin et al. 1999). Much effort has been devoted to investigate the structural and engineering properties of the basin, especially the Central Geological Survey (CGS 1999) in the ninety's. Over 30 wells were drilled, 17 of which reached the Tertiary basement. Some of these wells concentrated on detecting the Sanchiao fault (Lin et al. 1999). This drilling effort has added a great deal to the understanding of the structure of the Taipei basin. This paper summarizes the shallow reflection seismic results we have obtained over the past decade. After archiving these results and comparing them with the CGS's well data, we ought be able to better describe the basement shape, the layer structure, and the velocity structure, including the $\mathrm{P}$-waves and the $\mathrm{S}$-waves, of the Taipei basin. These data are likely to be of fundamental importance in the seismic study of basin effects for Taipei city and neighboring areas.

\section{GEOLOGIC BACKGROUND}

The Taipei basin is considered to be structure forming in origin. From the Pliocene to the Pleistocene age, three reverse faults developed in this area, along the western Taiwan foothills (Wang Lee 1969). They are (from NW to SE), the Hsinchuang fault, the Kanchiao fault and the Taipei fault (Fig. 1); all trend in the NE-SW direction. At this period, the Linkou area was a delta fan at the foot of this fault-generated hill, where gravels and conglomerates were widely deposited. About 400 thousand years ago, the tectonic pattern in northern Taiwan changed (Teng et al. 2000) and the area was "flipped" to become a tensile environment. One of the reverse faults, i.e., the Hsinchuang fault, altered its sense of movement and became a normal fault, now called the Sanchiao fault, which caused the Taipei basin to sink. This tectonic expansion could have been induced by a pure tension (Teng et al. 2001) or by a pull-apart mechanism (Lee et al. 1999), which caused the basin to assume its triangular shape. Thus, the deepest part of the basin is along the NW border, where the Sanchiao fault is located. This one-sided subsidence made the basin's Tertiary basement in a half-graben shape (Fig. 1b; Wang et al. 1994, 1995). Four newly deposited unconsolidated strata were overlying the basement (Fig. 2; Teng et al. 2001). Of these, the middle Chingmei Formation is mainly composed of gravels. It separates the overlying silt-dominated Sungshan Formation and the underlying sand-and-silt Wuku Formation and the gravel-rich Banchiao Formation. Their ages are 400 (Banchiao), 250 (Wuku), 100 (Chingmei), and 30 (Sungshan) thousand years (Ka), respectively. The topmost Sungshan Formation is quite soft and weak, which has led to earthquake damage and engineering troubles (Wen et al. 1995). 
(a)

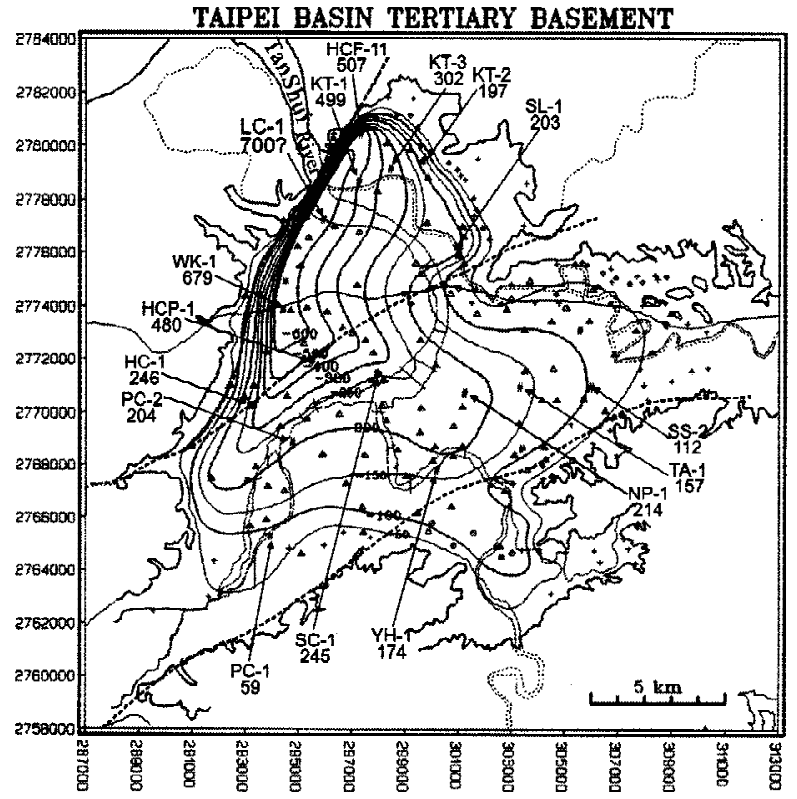

(b)

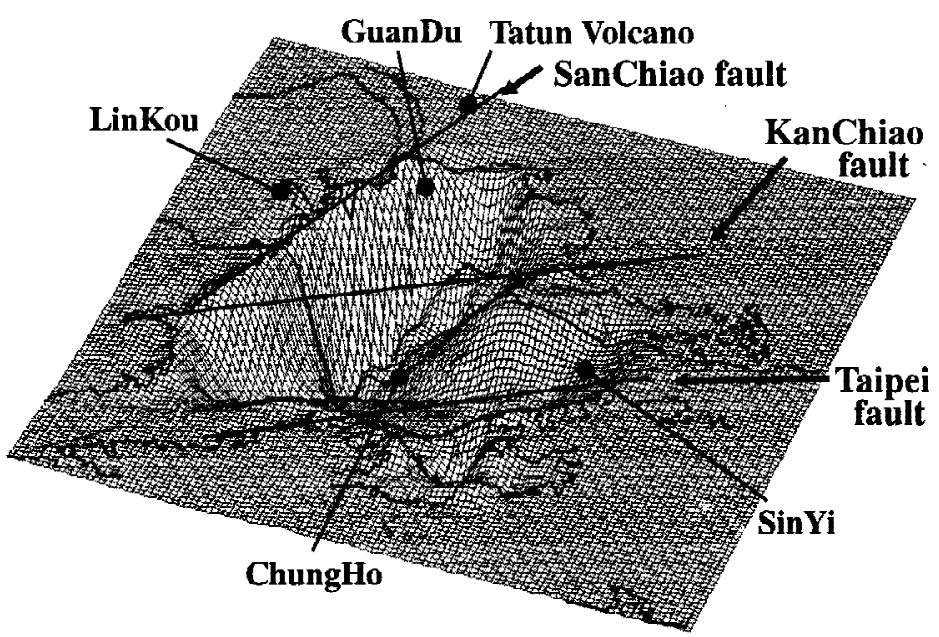

Fig. 1. (a) The Tertiary basement depth contours of the Taipei basin overlying the Tertiary basement. The triangles indicate the reflection seismic lines and the "\#" symbols are the CGS wells (name and depth are attached). (b) A stereo plot of the shape of the Tertiary basement. Three faults are indicated. There was obvious sinking along the Sanchiao fault, which has made the northwestern part of the Taipei basin a deep depression. 
The CGS has drilled over 30 boreholes throughout the Taipei basin since 1992, in an attempt to investigate the configuration of the basin. Their interesting findings are: 1) the deepest point is probably near the Wuku well (WK-1, 679 m; Fig. 1a) which is located almost at the middle of the basin segment of the Sanchiao fault (Lee et al. 1999), 2) the Guandu plain (northern basin) has an unexpectedly deep basement, perhaps more than $500 \mathrm{~m}, 3$ ) two layers of volcano-related lahar, with ages of 200 and $400 \mathrm{Ka}$, respectively, were found buried at depths of 240 - $320 \mathrm{~m}$ and 400 - $480 \mathrm{~m}$ in the Guandu area (Tsao et al. 2001), 4) the Sungshan and Chingmei Formations are levelly deposited above the Sanchiao fault (CGS 2003, p.118). By combining the CGS's data with the shallow seismic mapping, we can depict the shape of the Taipei basin, as shown in Fig. 1. A representative cross section is illustrated in Fig. 2, which has also been regulated by the well data present in Teng et al. (1999).

\section{SEISMIC REFLECTION SURVEYS}

We have collected a lot of shallow seismic reflection data throughout the Taipei basin (triangles in Fig. 1a) (Wang et al. 1994, 1995). It was quite a challenge to carry out the seismic work in such a heavily populated city. The large survey system used for oil exploration was obviously not suitable; instead, a small system of shallow seismic reflections were found to be more convenient. The shallow seismic method has the merits of mobility, efficiency, highresolution and cost-effectiveness (Steeples and Miller 1990). The small size made it easy to move around in the city. Most of the seismic lines had lengths less than $500 \mathrm{~m}$, and could be

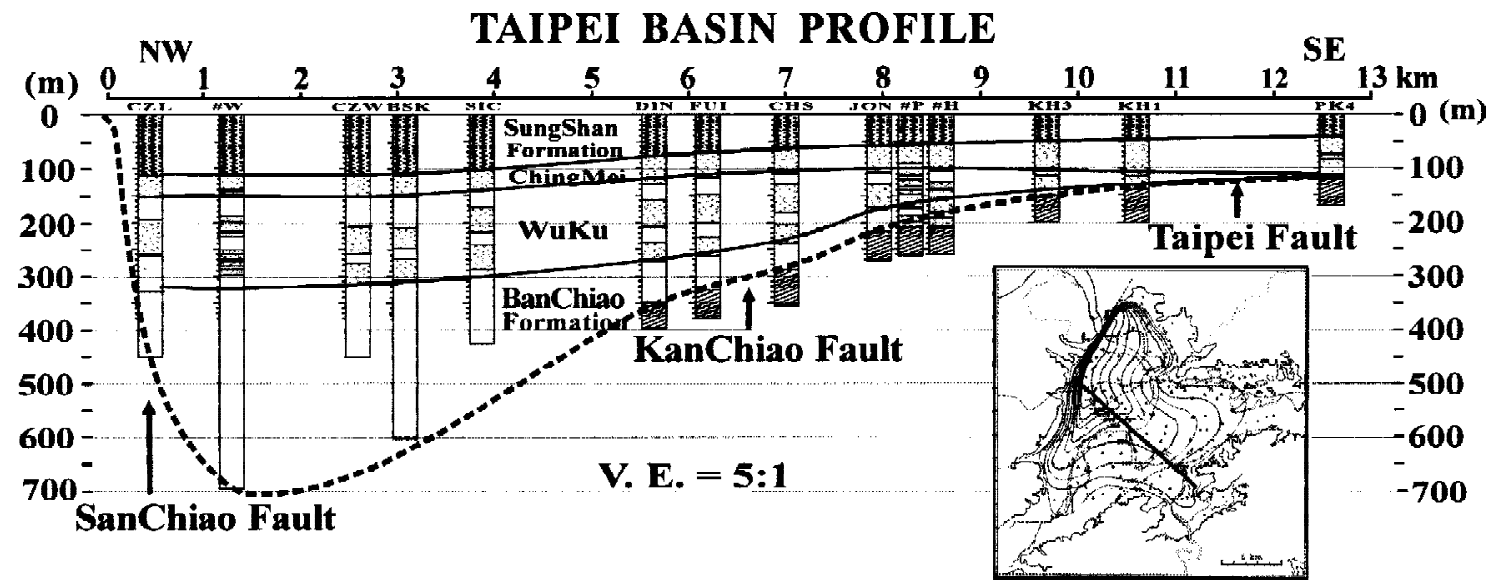

Fig. 2. A profile across the Taipei basin perpendicular to the strikes of the faults. The Sanchiao fault controls the deep depression on the northwestern Taipei basin. In contrast, the Kanchiao fault forms a boundary which separates the deep NW and the shallow SE parts of the basin. (partly modified from Teng et al. 2001, partly the seismic data) 
deployed in narrow streets or public places (such as parks, schools). These lines were spread out over a wide region to form a regional distribution. A 3D-like structure can be obtained when these distributed data are compiled together, and adjusted by the well logs. In this respect, the shallow reflection seismic sections can be thought of as artificial well logs, using which we can extend the borehole data to neighboring areas.

The survey equipments used in this study were: 1) source: EWG-III impact pulse generator, 2) receiver: OYO $40 \mathrm{~Hz}$ geophone, 3) recorder: DAS-1 48-channel seismograph, and the survey parameters were: 1) source interval: $4 \mathrm{~m}, 2$ ) receiver interval: $2 \mathrm{~m}, 3$ ) near-offset: $60 \mathrm{~m}$ or $100 \mathrm{~m}, 4$ ) fold: 12 or 16, 5) sampling rate: $0.25 \mathrm{~ms}$, 6) low-cut filter: $40 \mathrm{~Hz}$. Most of the field work was carried out in the early night to avoid traffic noise, and also not to disturb neighborhoods too much. The data processing followed standard CDP data processing, except for the emphasis of some dip filters and static corrections.

Although some seismic sections have already been published (Wang et al. 1994, 1995; Wang and Sun 1999), those in the NW portion of the basin are worth of further examination. Figures 3 and 4 show these sections. The vertical and horizontal axes of the seismic sections in this paper have been adjusted to the 1:1 scale in order to approximate real underground structures. Figure 3 shows the seismic sections aligned in a south-north direction and Fig. 4 in the westeast direction. The WK-1 and LC-1 well data are also utilized to connect the lithologic units and the seismic layers. The most dominant phase in the seismic sections is probably the Chingmei Formation. The coarse gravels in this layer cause seismic signals to reverberate. The other easily identified seismic phase is the boundary between the Wuku and Banchiao Formations, where the lithologic properties change (due to the appearance of gravel, massive mud, or even lahar layers). One surprising feature of Fig. 3 is that the deep layers in the Wuku and Banchiao Formations keep dipping toward the north. This implies that the basement is probably deeper in the north of this seismic profile. The deepest part mostly lies close to the outlet of the Tanshui River, not at the WK-1 position as has been commonly thought.

Figure 4 further confirms that the deepest part of the basement is actually along the line passing through the LC-1 well. The lithological and seismic layer relationships in this profile are not difficult to establish. Figure 4 shows a well log profile consisting of 12 aligned wells (adopted from CGS 2003, p.120) on the western border, called the Chentzuliaw (CZL) profile. When combined with the CZL section, we may construct a slanted basement, stretching from the edge toward the center, with an inclination angle of about 30 - 40 degrees. This means that it may be less than $1 \mathrm{~km}$ from the edge to a depth of $700 \mathrm{~m}$. Details of structural variations across the NW boundary are nicely presented in this profile. Figure 5 shows another seismic section taken near the basin's western border (Fig. 3a). The data quality in this section is not very good, but still recognizable. This is a long section $(1.3 \mathrm{~km})$, passing through the Wuku flood discharge area. A small depression is visible in the middle, but only for the deep layers. The top Chingmei and Sunshan Formations are nearly flat, even making an angular contact with the Wuku Formation (see the western edge at 0.2 seconds). The section in Fig. 5 nicely describes the shape of the basin's structure at or near its deepest center.

To investigate the lahar (volcanic debris flow) deposits, we also collected a long seismic line in the Guandu area, northwestern Taipei basin (Fig. 3a). It is composed of two separate lines (DADU and KDU) (Fig. 6). Several wells give the control points (wells KT-1, SCF-8, 
(a)
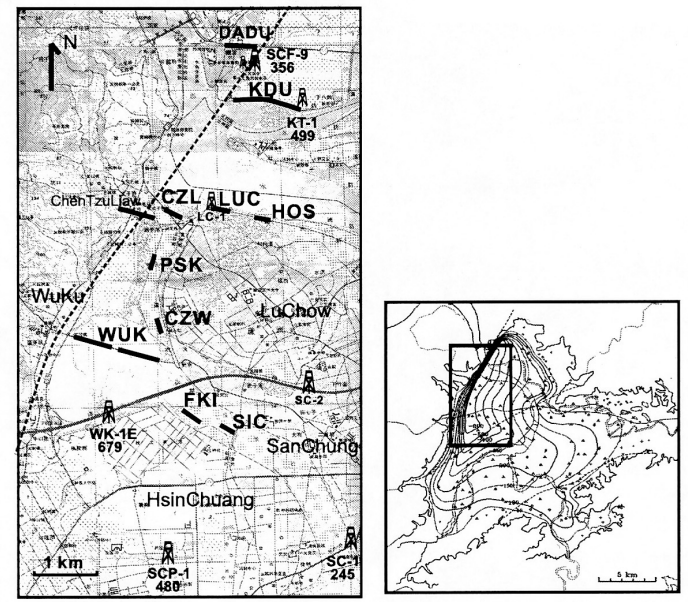

(b)

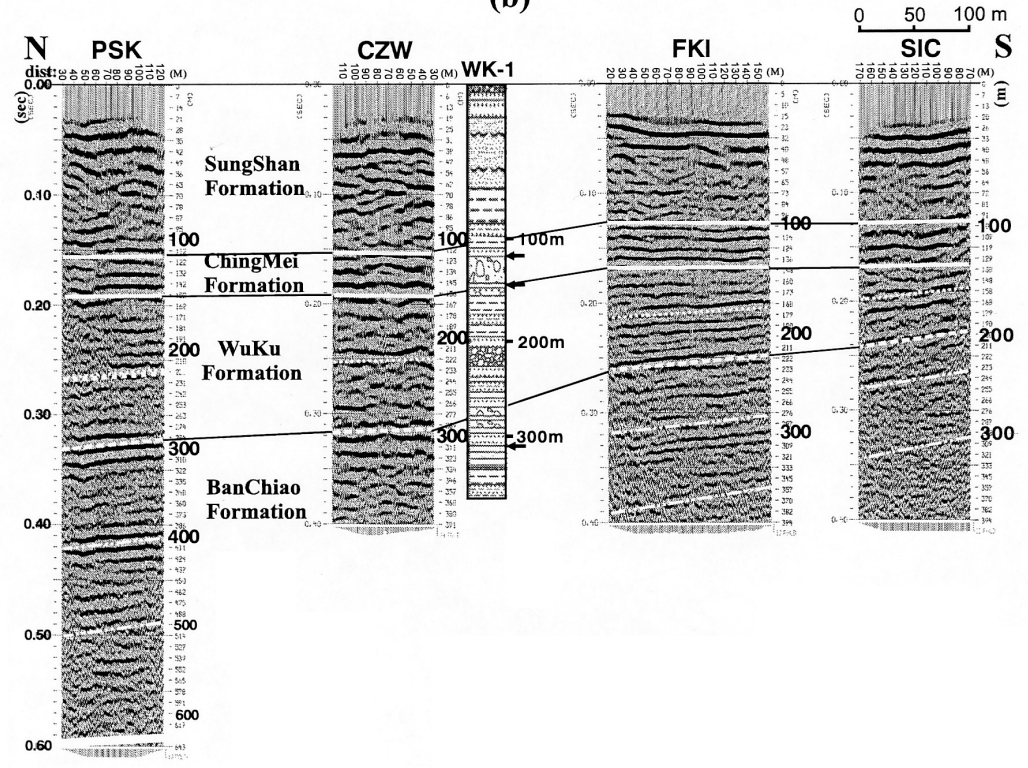

Fig. 3. Shallow reflection seismic sections in the northwestern Taipei basin. (a) is a map showing the position of each section, (b) contains four sections roughly aligned in a NS direction. The horizontal and vertical scales of all the seismic sections in this paper have been set to approximately the same scale. The lithological log of well WK-1 (adopted from Teng et al. 2001 ) is attached for comparison. The arrows on this log indicate the different layers' boundaries. It is interesting to see that the layers continuously decline toward the north, which implies a deeper basement to the north. 

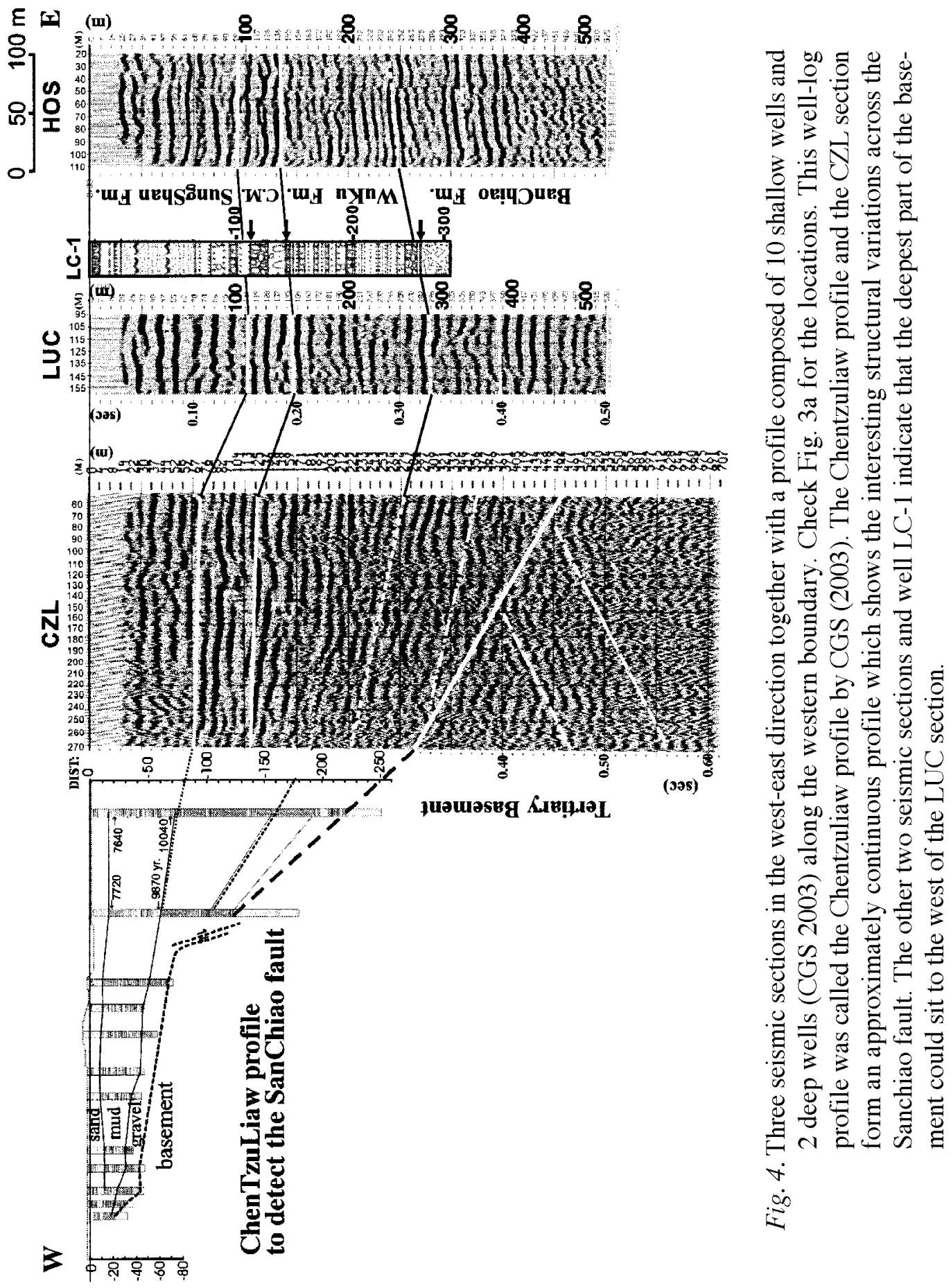
(W)

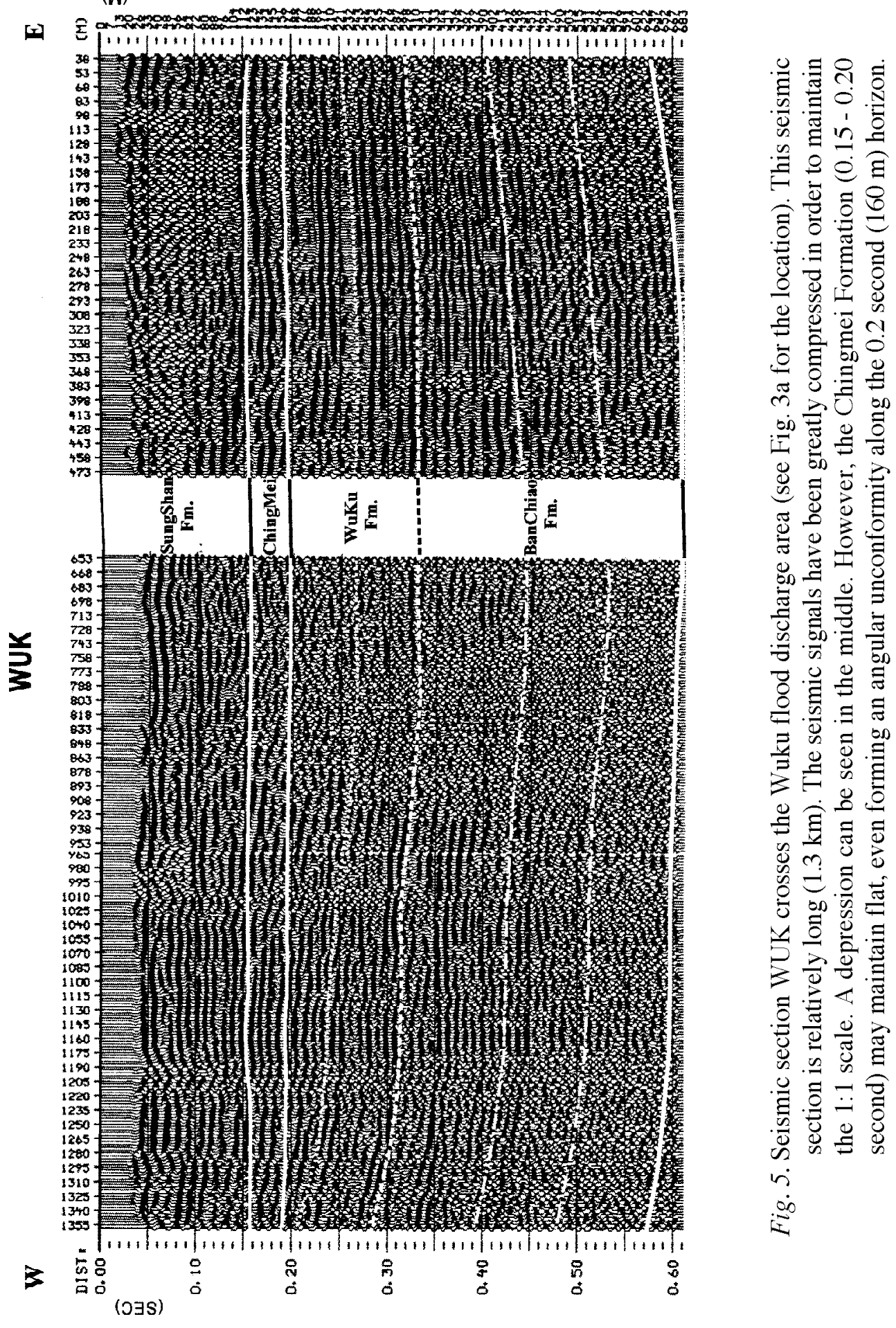


Wang et al.

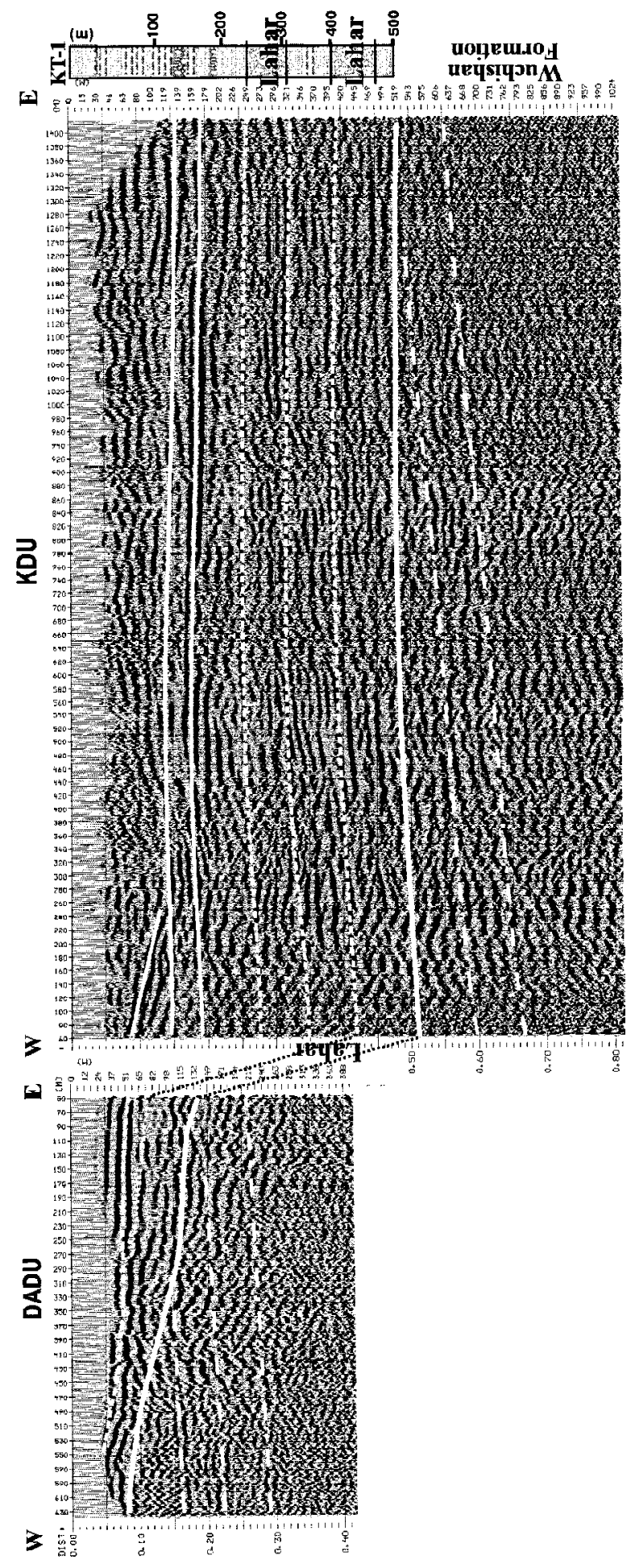

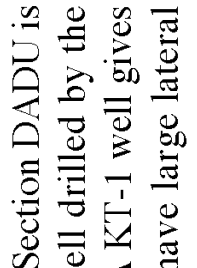

$\dot{=} \geqslant$

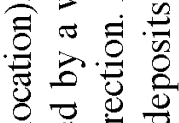

응 융

结突

ठ잉

요 $\stackrel{\Xi}{0}$

递芯芯员

Ð $\vec{\Xi}$

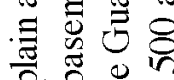

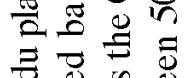

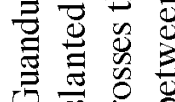

可 $\frac{\pi}{0} 00$

至象象

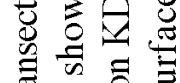

플 응

官卷

帘完

完范芯

㐫灵宅

言要

要曹

.0 约

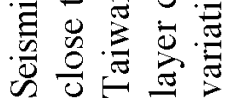

c。

$\dot{8}$ 
SCF-9; Fig. 3a). Section DADU gives a nicely sloped surface of the basement, above which deposits mixed lahar material with quite low P-wave velocity and low frequencies. On the contrary, the layers in section KDU are relatively flat. The KT-1 well (basement at $499 \mathrm{~m}$ ) is located at the right corner of this section to provide layer controls. The basement surface has a little tilt toward the west, below which a dipping Wuchishan Formation (an early Miocene strata) forms an angular-unconformity contact. The basement in the Guandu area is estimated less than $550 \mathrm{~m}$ deep. The fast lateral changing phases for the lahar layers are obvious, due to their debris nature. But this layer is basically flat. The strong reflection at 0.2 seconds could correspond to the gravel deposits of the Chingmei Formation.

\section{S-WAVE SEISMIC REFLECTION SURVEYS}

The topmost Sungshan Formation in the Taipei basin is quite soft. It is composed of unconsolidated sand, silt and clay, with a thickness between $50 \mathrm{~m}$ (SE) and $120 \mathrm{~m}$ (NW) (Fig. 7). Most of the earthquake-related damage and the engineering troubles can be attributed to the destructive behavior of this loose layer. Figure 7b, adopted from Wen et al. (1995), illustrates the magnification of the seismic waves (shown as the peak ground acceleration, PGA) at different depths, observed at the WK-1 well. Most site effects have been concentrated in the top $140 \mathrm{~m}$. The shape of this Sungshan Formation can be obtained by seismic reflection surveys and the data from numerous engineering wells as is shown in Fig. 7a. Except for a deeper part to the $\mathrm{NW}$, there is a local depression to the east, near the Taipei airport.

In order to study the earthquake response of the Sungshan Formation, we also conducted $\mathrm{S}$-wave seismic reflection surveys in the Taipei basin. This work was much tougher than the Pwave survey due to the difficulty in handling shear-wave sources. We used a sledge hammer horizontally striking a $1 \mathrm{~m}$ long railroad rail iron that was damped by an automobile riding on it. The generated S-wave signal was weak, and usually out of phase for different strikes, which makes it impossible to enhance the data by stacking. We took five records at each location, and picked the better ones to process in the laboratory. Figure 8 shows examples of the recorded $\mathrm{S}$-wave and $\mathrm{P}$-wave reflection signals. Here a walk-away type of data acquisition (moving one receiver spread-length for each shot, and 3 or 4 shots for one survey) was applied to get profiles which would be long enough to provide reliable velocity analysis. It is noticed that $\mathrm{S}$-wave signals exist within the near-source time window (Fig. 8a, lower-left corner), thus no near-offset is necessary. The receiver interval is kept as small as $1 \mathrm{~m}$ for its short effective travel distances. Figure $8 \mathrm{~b}$ also shows how to get the $\mathrm{S}$-wave velocity by simply fitting hyperbolic curves with appropriate velocities. Due to the weak signals, the S-wave surveys were usually carried out in the later night. Small survey noise and size made it easy to move, thus facilitating the search for suitable survey locations. Figure 8a also indicates the feasible $\mathrm{P}$-wave window, which is at the far and upper corner. Figure $8 \mathrm{c}$ gives the P-wave walk-away velocity estimation. Relatively low velocities are noticeable for both the $\mathrm{S}$ - and the P-waves. The velocity values obtained from the walk-away acquisitions are then converted into layer velocities based on the Dix equation (Yilmaz 1987).

Using walk-away type surveys, we collected more than $100 \mathrm{~S}$-wave velocities throughout 
(a)

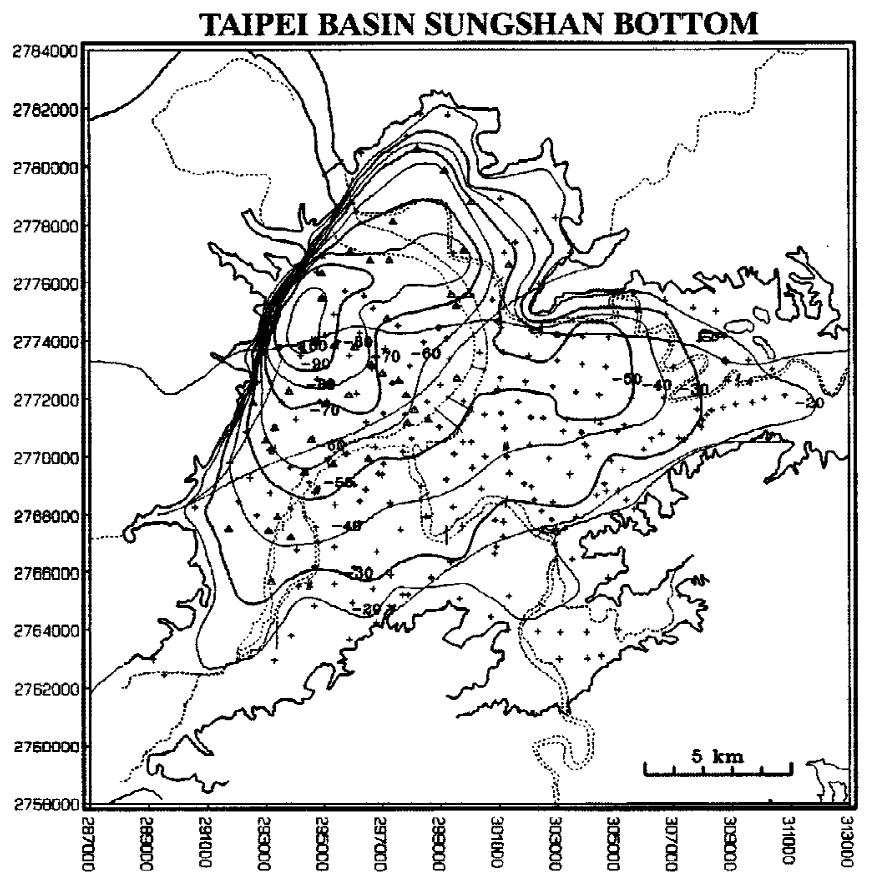

(b)

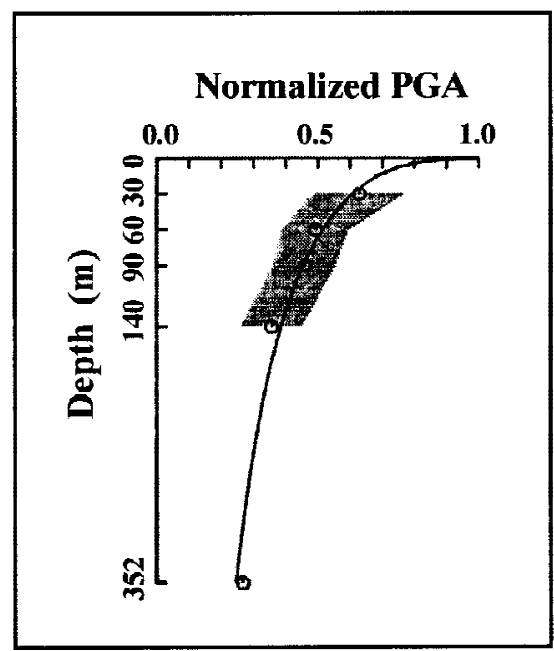

Fig. 7. (a) shows the depth contours of the Sungshan Formation which is the topmost strata of the basin, (b) measures the PGA magnification in the Sungshan Formation (top $100 \mathrm{~m}$ ) at the WK-1 well (adopted from Wen et al. 1995). Most of the seismic wave magnifications are concentrated in this soft layer. 
(a)

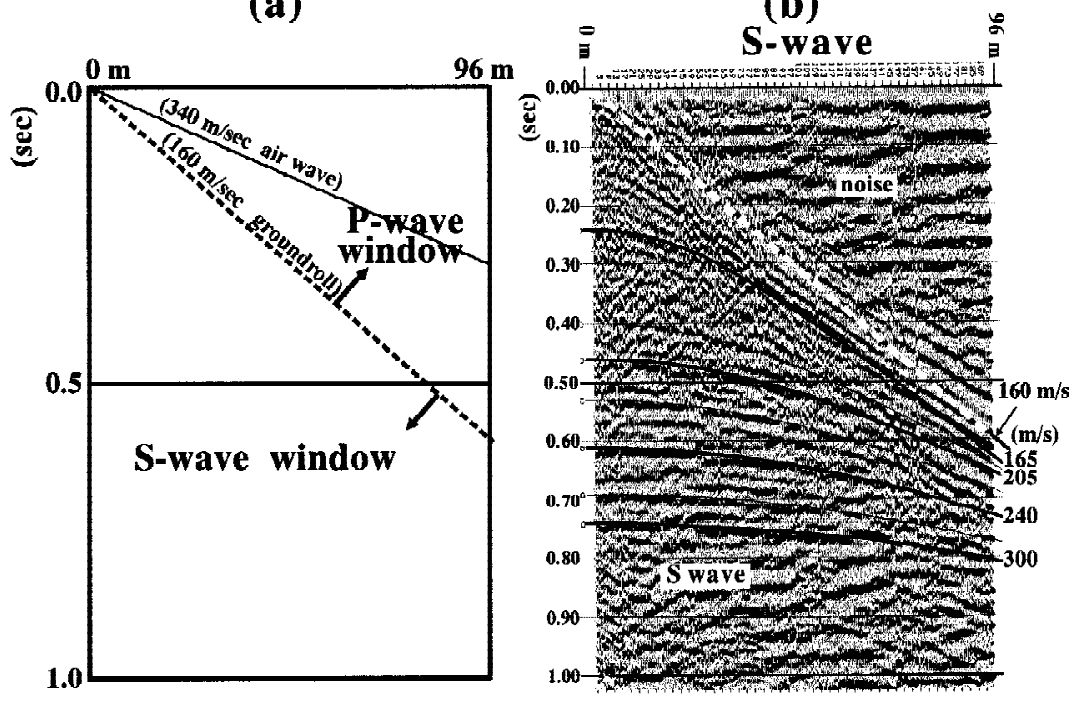

(c)

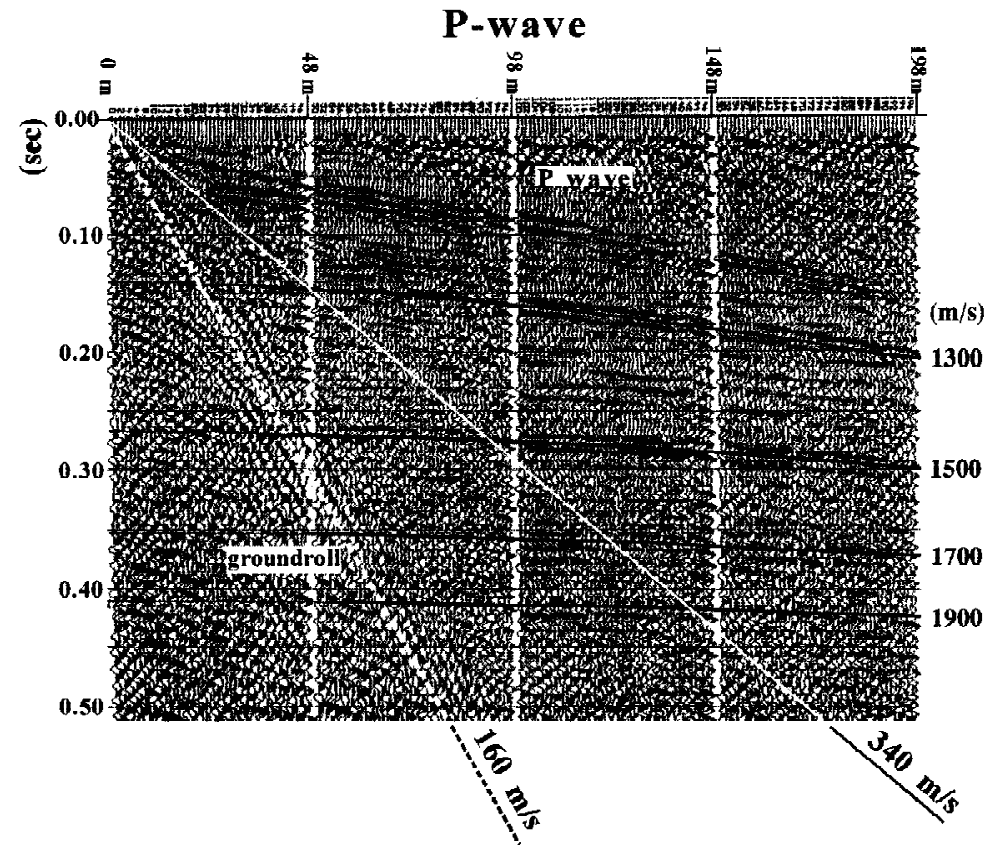

Fig. 8. The concepts leading to obtaining the $\mathrm{P}$ - and $\mathrm{S}$-wave velocities in seismic reflection surveys. (a) gives the time windows where the S-wave (lowerleft corner) and the P-wave (up-right corner) signals prevail, (b) and (c) respectively show the real data from which the velocities of the S- and Pwave are measured. The velocities are obtained according to the hyperbolic travel time assumption. 
the basin area. Details of the results can be found in Lee (1996). Figure 9 shows one P-wave and one S-wave velocity profile along the same line as that in Fig. 2. Only the S-wave velocities of the Sungshan Formation are presented because of the weak S-wave sources used. Three S-wave velocity layers $\left(170,230,340 \mathrm{~m} \mathrm{~s}^{-1}\right)$ are found inside the Sungshan Formation. These three velocity layers possibly correspond to the three deposition cycles of the Sungshan formation. The $\mathrm{S}$-wave velocity for the lower Chingmei formation is around $450 \mathrm{~m} \mathrm{~s}^{-1}$. Figure 9 a shows the P-wave velocities for the whole depth; the values are $1500-1600 \mathrm{~m} \mathrm{~s}^{-1}$ and $1700-1800 \mathrm{~m} \mathrm{~s}^{-1}$ for the Sungshan and Chingmei formations, respectively. All the velocity values in the Taipei basin are actually quite low, especially that $S$ velocities, which are only about one fifth of the $\mathrm{P}$-wave velocities. These low $\mathrm{S}$-velocities could be related to the main factor affecting the site conditions. Table 1 lists the $\mathrm{P}$ - and $\mathrm{S}$-wave velocity values for the whole basin. The S-wave

(a)

P-wave velocity

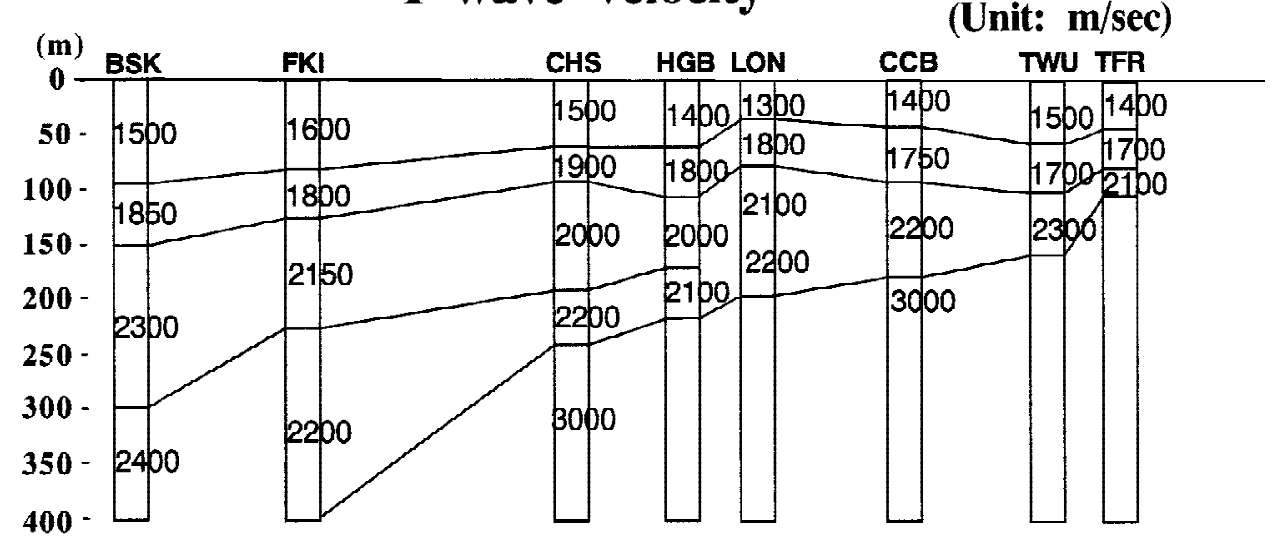

(b)

S-wave velocity

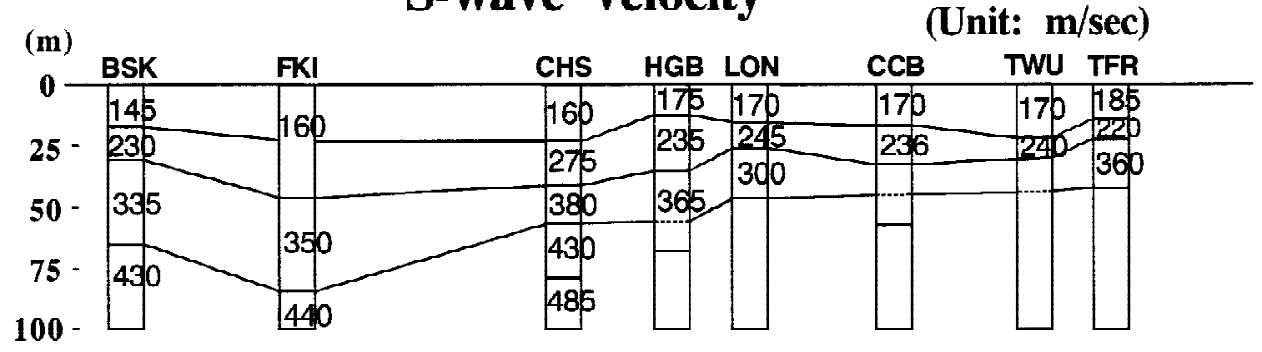

Fig. 9. The P-and S-wave velocity distributions in the Taipei basin. The same profile as in Fig. 2 is chosen. Only the S-wave velocity in the Sungshan Formation in (b) is shown. (after Wang and Sun 1999) 
velocities of the deep part are just for reference. They were observed at several survey lines where the basement is shallow.

Table 1. P- and S-wave Velocities in the Taipei Basin.

\begin{tabular}{|c|c|c|c|c|}
\hline & \multicolumn{2}{|c|}{ Depth (m) } & \multirow{2}{*}{$\begin{array}{r}\text { P-wave } \\
(\mathrm{m} / \mathrm{sec})\end{array}$} & \multirow{2}{*}{$\begin{array}{c}\text { S-wave } \\
(\mathrm{m} / \mathrm{sec})\end{array}$} \\
\hline & NW & $\mathrm{SE}$ & & \\
\hline \multirow{3}{*}{$\begin{array}{l}\text { Sungshan } \\
\text { Formation }\end{array}$} & $0-20$ & $0-15$ & 450 & 170 \\
\hline & $20-50$ & $15-35$ & 1500 & 230 \\
\hline & $50-100$ & $35-50$ & 1600 & 340 \\
\hline $\begin{array}{l}\text { Chingmei } \\
\text { Formation }\end{array}$ & $100-160$ & $50-100$ & 1800 & 450 \\
\hline $\begin{array}{l}\text { Wuku } \\
\text { Formation }\end{array}$ & $160-320$ & $100-200$ & 2000 & $600 ?$ \\
\hline $\begin{array}{l}\text { Banchiao } \\
\text { Formation }\end{array}$ & $320-700 ?$ & $200-300$ & 2200 & $880 ?$ \\
\hline $\begin{array}{l}\text { Tertiary } \\
\text { Basement }\end{array}$ & & & 3000 & $1500 ?$ \\
\hline
\end{tabular}

\section{DISCUSSION AND CONCLUSIONS}

The seismic reflection surveys were difficult to carry out in the urban area, however, we could still obtain significant results after careful field work design and data processing. It took seven years to collect the data discussed in this paper. The basin structures, especially, the basement depths were found after compiling hundreds of seismic records from the whole ba$\sin$ area.

It is interesting to see that the Kanchiao fault forms a boundary that separates the basin into two halves. The NW part has a deep bottom, greater than $500 \mathrm{~m}$, with 4 layers, while the SE part is shallower, less than $300 \mathrm{~m}$, dominantly 2 layers (the bottom two layers pinch out). This fundamental difference in the basin's structure should be noted when simulating seismic wave propagation through the basin.

Both the P-wave and S-wave surveys produced good results. Figure 10 shows an interesting comparison of the obtained S-wave velocity structure with the PGA distribution of strong motion records; averaged for 50 earthquakes. The regional S-wave velocity distribution is calculated by the thickness weighted averaging of the S-wave velocities in the Sungshan Formation. The apparently large magnification of the stations at the SE border of the basin, i.e., the Sinyi district (see Fig. 1b for locations), where Taipei's City Hall is located, is quite obvious. Here, and at the northern (Guandu) and southern (Chungho) border, have relatively low $\mathrm{S}$-wave velocities, so might suffer greater site amplification. Figures 10c, d show comparison of the averaged S-velocity values and the site PGA magnifications, along a line given in Fig. 10b. There is good correlation. It is no doubt that the low S-wave velocity is the main factor giving rise to high PGA's. A good and widely distributed S-wave velocity survey could 
adequately provide the necessary information to estimate the site-amplification effect in the Taipei basin.

(a)

Average S-wave Velocity

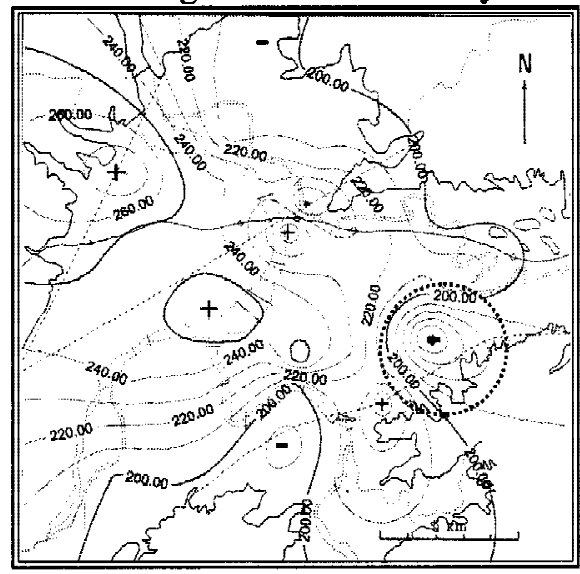

(c)

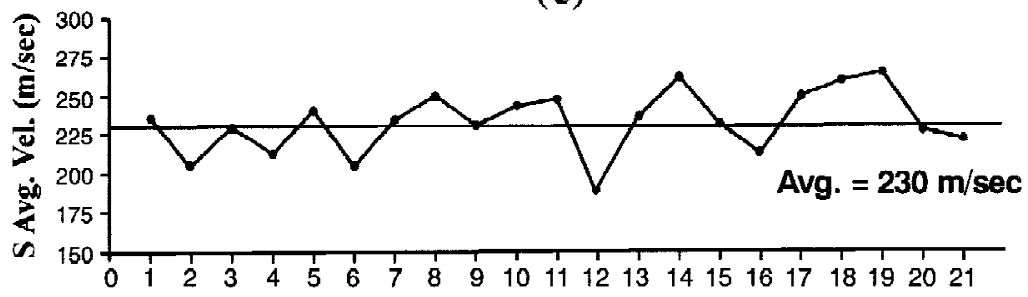

(d)

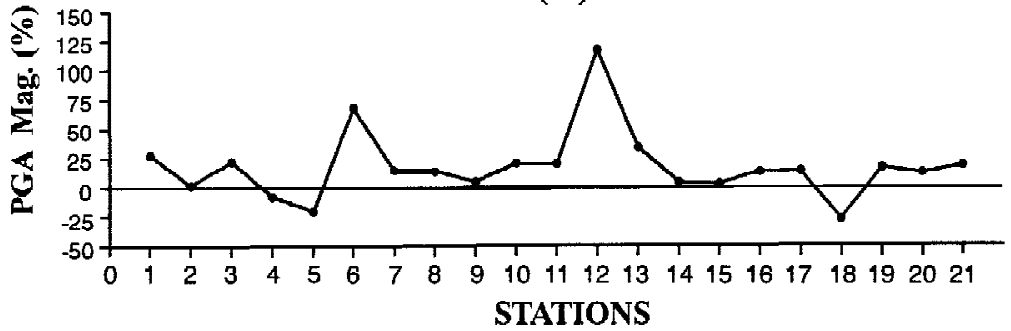

Fig. 10. (a) The average S-wave velocity distribution of the Sungshan Formation. The averages are calculated by taking the thickness of the layer as the weighting. (b) The average PGA distribution calculated from 50 significant earthquakes. The distribution patterns in the two figures are quite similar. (c) Several stations in the southeastern basin are picked to show the close relationship between the high PGA magnifications and the low $\mathrm{S}$-wave velocities. 
The Sungshan Formation consists of interbedded coarse-grained sand and fine-grained mud that attribute to its brackish water fluvio-lacustrine sedimentary environment, dating from the late Pleistocene to the recent epoch (Teng et al. 2001). Three rivers have flowed into the basin at different periods of time, bringing in different grain size fluvium. Figure 11 compares the sediment material distribution and the S-wave velocities at different depths of the Sungshan Formation. The sediment distribution patterns are taken from Hsu (1994) who classified the Sungshan Formation into 8 sub-layers, representing the development of different river systems. In Fig. 11, the shear velocity distributions appear to be quite consistent with the sediment deposition patterns. This clearly indicates that the site amplifications in the Taipei basin are actually a result of the sediment distribution. From these figures, we also find that the Sinyi district has thick-bedded mud deposits which induce ever greater site effects.

From the seismic sections obtained in the NW basin (Figs. 3, 4, 5 and 6), we have found that: 1) the deepest point could be located at the outlet of the Tanshui River, instead of at the WK-1 well, 2) the Chingmei and Sungshan Formations, or even the lahar layer in the Guandu plain, are generally flat, and 3) the drop of the basement depth is quite sharp along the boundary. We propose a model to summarize these observations: the Sanchiao fault may be long enough to extend beneath the Tatun volcanic region to the north. This makes the Tanshui River outlet be located at the middle of the fault, which may fit more to the faulting pattern of the pull-apart basin model. From relatively flat deposits of the topmost layers on the seismic profile collected at the Guandu plain (Fig. 6), we propose that this fault could be more active before $200 \mathrm{Ka}$ (i.e., before the deposition of the Banchiao Formation as well as the lahar), and the Tatun volcano may also be involved in the fault movement in this period. The basin may have become relatively quiet after the $100 \mathrm{Ka}$ and the upper flat layers were deposited. However, the quiet deposit of the Sungshan Formation is only an overall observation, and more data is required to verify activity of the Sanchiao fault during the later $100 \mathrm{Ka}$.

From the above discussions, we obtain the following conclusions:

1) The shape of the Taipei basin looks like a half-graben. The part along the NW border, where the Sanchiao fault is located is quite deep, however, the deepest place could actually be at the outlet of the Tanshui River.

2) The old Kanchiao fault forms a boundary which separates the basin into two parts. Each part has a different basement depth and differently deposited layers.

3) The shape of the basement in the NW basin suggests that the Sanchiao fault may include a segment passing through the Tatun volcano and was found to be more active during the first half $(200 \mathrm{Ka})$ of its existent period $(400 \mathrm{Ka})$.

4) The upper Sungshan Formation is closely related to the basin effect for earthquakes. This layer has a thickness of around $50-120 \mathrm{~m}$ and possesses quite "soft" deposits with very low S-wave velocities $\left(120-350 \mathrm{~m} \mathrm{~s}^{-1}\right)$.

5) The S-wave velocity distribution apparently controls the PGA magnification in the basin. These S-wave velocities are also closely related to the sediment depositions. Sufficient evidence has been observed to confirm this low S-wave velocity effect.

Acknowledgments This research was supported by the National Science Council under grants NSC90-2116-M-008-003 and NSC91-2116-M008-002. Rich information on the Taipei basin 
(a)

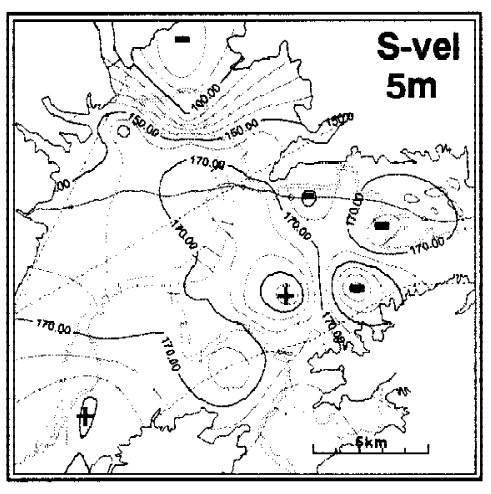

(c)

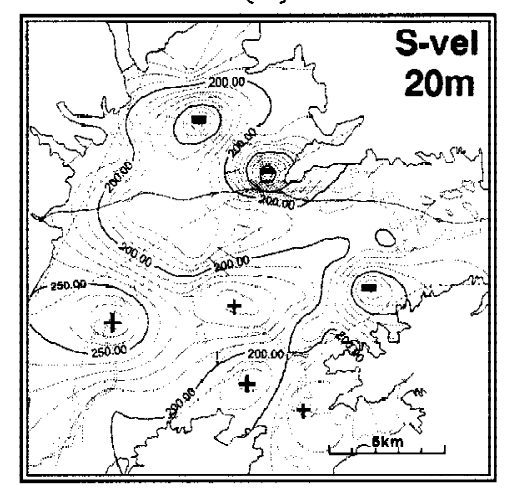

(e)

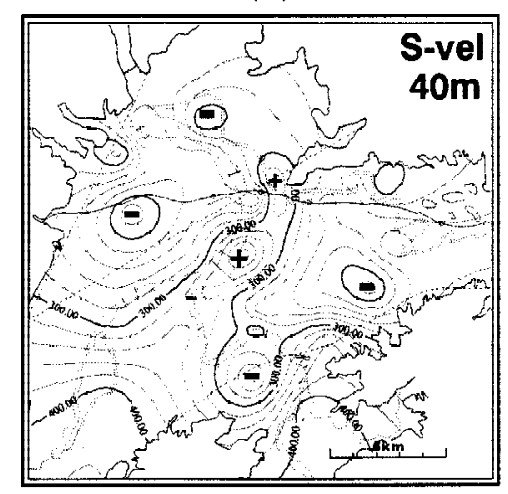

(b)

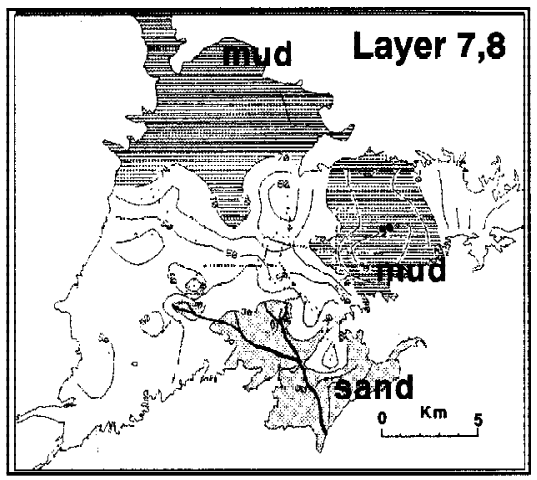

(d)

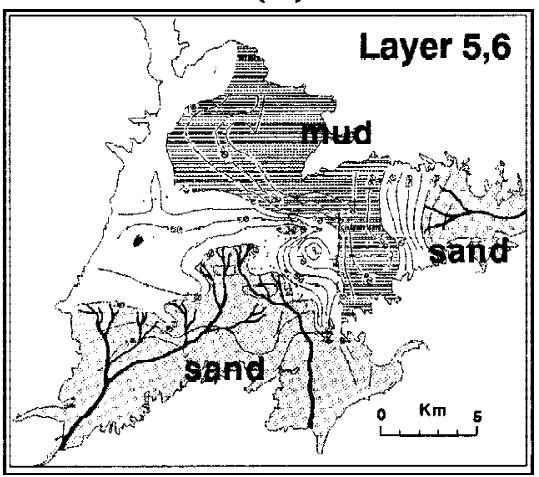

(f)

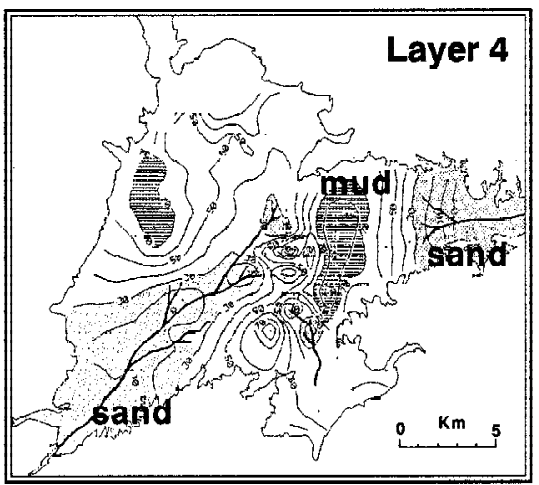

Fig. 11. The close relationship of S-wave velocities and the mud-sand contents at different depth levels in the Sungshan Formation. The Three panels compare the three different depths. The low S-wave velocities may be due to the high mud content. (b, d, f modified from Hsu 1992) 
provided by CGS largely benefits this study, and is highly appreciated. We also thank many undergraduate and graduate students who devoted large amounts of labor to the field work. Great gratitudes are also extended to two anonymous referees for their valuable and constructive comments.

\section{REFERENCES}

Bonilla, M. G., 1977: Summary of Quarternary faulting and elevation changes in Taiwan. Mem. Geol. Soc. China, 2, 43-46.

Central Geological Survey, 1999: Subsurface Geology and engineering environment of Taipei Basin, Central Geol. Surv. Spec. Pub., 11, MOEA, ROC, 406pp.

Central Geological Survey, 2003: Annual report of the Central Geological Survey (2002), MOEA, ROC, 182pp.

Hsu, C., 1992: A preliminary study of the lithology of Sungshan formation in Taipei basin. Master thesis. Nat. Taiwan Univ., Taipei, Taiwan.

Lee, J. F., C. C. Lin, D. C. Lai, T. W. Su, Z. L. Chiu, and C. J. Zeng, 1999: The study on the formation of Taipei basin. Central Geol. Surv. Spec. Pub., 11, 207-226.

Lee Y. H., 1996: Investigating S-wave Velocity Structure of Sungshan Formation in Taipei Basin Using Reflection Seismic Method, master's degree thesis. Nat. Central Univ., Chungli, Taiwan.

Lin, C. J., D. G. Lai, L. Y. Fei, H. C. Liu, J. G., Gi, and T. Y. Si, 1999: The deep drilling in the Taipei basin (1992 - 1996). Central Geol. Surv. Spec. Pub., 11, 7-39.

Steeples, D. W., and R. D. Miller, 1990: Seismic reflection methods applied to engineering, environmental, and groundwater problems. In: Ward S. H., (Ed.) Geotech. and Environ. Geophys. Vol. I: Review and Tutorial. SEG publications, 1-30.

Sokolov V., C. H. Loh, and K. L. Wen, 2001: Empirical models for site- and region-dependent ground-motion parameters in the Taipei area: a Unified Approach.Earthq. Spectra, 17, 313-331.

Teng, L. S., C. T. Lee, Y. B. Tsai, and L. Y. Hsiao, 2000: Slab breakoff as a mechanism for flipping of subduction polarity in Taiwan. Geology, 20, 155-158.

Teng, L. S., C. T. Lee, C. H. Peng, W. F. Chen, and C. J. Chu, 2001: Origin and geological evolution of the Taipei basin, northern Taiwan. Western. Pac. Earth Sci., 1, 115-142.

Tsai, Y. B., and M. W. Huang, 2000: Strong Ground Motion Characteristics of the Chi-Chi, Taiwan Earthquake of September 21, 1999. Earthq. Eng. Eng. Seism., 2, 1-21.

Tsao, S. J., S. R. Song, and C. Y. Lee, 2001: Geological implications of lahar deposits in the Taipei basin. Western. Pac. Earth Sci., 1, 213-226.

Wang, C. Y., W. C. Hsiao, and C. T. Sun, 1994: Reflection seismic stratigraphy in Taipei basin (I) - northwestern Taipei basin. J. Geol. Soc. China, 37, 69-95.

Wang, C. Y., Y. L. Tsai, and M. L. Ger, 1995: Reflection seismic stratigraphy in Taipei basin (II) - southwestern Taipei basin. J. Geol. Soc. China, 38, 141-172. 
Wang, C. Y., and C. T. Sun, 1999: Interpretation of seismic stratigraphy in the Taipei basin. Central Geol. Surv. Sepc. Publ., 11, 273-292.

Wang Lee, C. M., 1969: Petrology and origin of the Linkou gravel in Taipei, Taiwan.Proc. Geol. Soc. China, 12, 49-64.

Wen, K. L., L. Y. Fei, H. Y. Pen, and C. C. Liu, 1995: Site effect analysis from the records of the Wuku downhole array. TAO, 6, 285-298.

Yilmaz, O., 1987: Seismic data processing. SEG Publications, 526pp. 